\title{
ASSESSMENT KNOWLEDGE AND ATTITUDES STUDENTS COLLEGE CONCERNING PRECONCEPTION COUNSELING AND SCREENING
}

\author{
Dr. Sundss. Baqer Dawood, Dr. saijjad Salim Issa, \\ Dr. Jenan Akber Shakoor, Kazem J.almadwah
}

\section{Abstract}

Background: preconception counseling screening is one of the most effective ways to prevent or reduce the social and emotional burden on the family and society. As a result of the low level of knowledge about these tests among people, including university students who are the ideal sample, they are expected to marry. Pre-marital testing has been successful in many parts of the world.

Objectives: To Assess the knowledge and attitudes of students in the nursing college about the importance of preconception counseling and screening.

Methodology:The study consisted of 100 students (45 students for evening study and 55 students for morning study) in the College of Nursing for the third and fourth stages.A questionnaire was used as a data collection tool to achieve the objectives of the study to test the reliability of the questionnaire and the content was validated by eight experts. Statistical and inductive analyzes were used for data analysis

Results . The study showed that the assessment of the knowledge of the students of the College of Nursing regarding the preconception counseling was at anmoderate leveland that the assessment of Attitude was also at an moderate level. The study showed that the relationship was moderate by assessing the relationship between demographic variables, knowledge and Attu tied , P>0.05.

Conclusions: The study on preconception counseling and screening may be considered to be very important for increasing students' knowledge of post-graduate community education.

Conduct continuing education programs for preconception counseling and screening for high school and university students, And to increase cooperation between the Ministries of Higher Education and Scientific Research and the Ministry of Health and the Environment to develop a strategy to increase the knowledge of university students about the importance of pre-marriage examinations and to strengthen the role of clergy in ensuring the conduct of premarital tests to reduce genetic and infectious diseases among members of society

\section{Introduction}

Pre-conception care is the provision of the biomedical, behavioral and social health interventions to women and couples before conception occurs. It is aimed at improving their health status, reducing behaviors, individual and environmental factors which could contribute to poor maternal and child health outcomes. Preconception care includes the care before the first pregnancy and the care between the subsequent pregnancies.[1]It is therefore patient education, evaluation, and management aimed to prevent unplanned pregnancies and decrease the risk of adverse health effects for the woman, fetus, and neonate by optimizing the woman's health and knowledge before planning and conceiving a pregnancy. [1]

Preconception period is a period of three months before pregnancy occurs. It is the time 
where an individual make life changes that can help improve fertility, reduce health problems during pregnancy and aid in recuperation from childbirth. [2]

Since a majority of women and couples of reproductive age are normally unaware of the effects that their own health conditions and health-related behaviors may have on the fetus during pregnancy, preconception care addresses the care before pregnancy occur. Even though antenatal care is part of care in the Maternal, Newborn, and Child Health (MNCH), it begins too late thereby neglecting the most critical time of embryonic development which frequently occurs even before a woman knows she is pregnant. Evidence strongly suggests that earlier care before pregnancy leads to improved women's health and improved pregnancy outcome for both the mother and the newborn. Preconception care therefore is any intervention provided to women and couples of reproductive age, regardless of pregnancy status or desire, before pregnancy, to improve health outcomes for women, newborns and children. [2]

Prior to conception, specific health interventions would address most of the reproductive health risks including the age (age below 16 years and those above 35 years), the parity (primigravida and grand multiparity), Nutritional status (under nutrition, obesity and malnutrition), previous adverse effects (recurrent spontaneous abortions, still births, early neonatal deaths within one week, previous baby with congenital abnormalities), Medical conditions (anaemia, malaria, HIV/AIDS,TB, Diabetes, sickle cell anaemia, asthma, hypertension, STI/RTIs), previous obstetric complications (hemorrhage, Caesarean Section, preterm labour, eclampsia), Gender based violence (Female Genital Mutilation, early marriage, physical and psychological abuse, sexual violence) and low socio-economic status. Most of which appropriate health information and interventions would be given during preconception care visit.[3]

\section{Important of study}

According to world health organization, preconception health care is an essential component of reproductive health which focuses on the conditional and risk factors that could affect a women if she became pregnant, Sexual and reproductive health is fundamental for individuals, couples and families, as of communities and nations. well as for the social and economic development[4]

The concept of educating women before conception is a new strategy that would involve both women and men to foster healthy pregnancies and the delivery of healthy babies. Preconception care aims to reduce the likelihood of adverse health effects among women, fetuses, and newborns, as well as the number of unplanned pregnancies by enhancing a woman's knowledge and optimizing health before conceiving. Women can achieve optimal health by adequately participating in healthcare education activities. [1]

As an increasing proportion of women of reproductive age use medications, and few medications are examined for possible teratogen effects, women should discuss all usage of medications with their health care provider. if planning a pregnancy or becoming pregnant. Obesity (Body Mass Index, BMI, of 30 or above) is associated with increased risks both for infertility, and complications during pregnancy, such as preeclampsia and gestational diabetes, as well as complications during delivery [5].

Nurses need to know how to correct charting errors on a computer. The transition from paper to computer presents challenges for nursing staff, one of challenges of computerized documentation is inclusion of the nursing process [15].

\section{Objective of the study}

1. To Assessment knowledge and attitudes students concerning preconception counseling and screening (in nursing college) 
2. To describe socio - Demographic variable: age, gender, level of education of parent student, occupation of parent student, residency, socioeconomic status of parent student,relative relationship between of parent student and history diseases

3. To find out relationship between the describe socio - Demographic and knowledge and attitudes students.

\section{Methodology}

\section{Design of the Study}

A cross sectional study was carried throughout the present study,on aborted 100 nursing student in order to Assessment knowledge and attitudes students concerning preconception counseling and screening period (15th November /2018 to25th/ February /2019).

\section{Setting of the study}

The study was conducted at nursing student in morning and evening with in forth and third class.

\section{Sample of the Study:}

Non -probability sample (purposive -sample) consisted of four hundred (100) student nursing

\section{Tool used for data collection}

The instrument was designed and constructed by the investigators after reviewing related literature and previous studies which consisted of the following parts.

\section{Part one: Socio- Demographic Characteristics}

Demographic data relative to Socio- demographic data characteristic such as, mother age, mother and education level for study sample and their husband, occupation status for study sample and their socioeconomic status for family, according to: educational level,occupation,number of family, residence own or rent,number family member,

Part II: Knowledge students concerning preconception counseling and screening: Premarital tests are defined as the laboratory tests that the young man or the next young woman undergoes, Benefits, the mental health history of the disease RH type, universal precautions, meaning, Vaccination, Cause, Methods and prevention.(62 items)

Part III: Attitude students concerning preconception counseling and screening: perception, Intensity perception, Self - efficacy, Approval of education on prenuptial examinations, Encourage on, Agreement on premarital screening, barrier to taking action about premarital screening, Attitude student among premarital screening, and Agreement on the cause don'ts premarital screening.

\section{Validity of the instrument}

The content validity of the constructed questionnaire was determined through the use of a panel of experts to investigate the content of the questionnaire for the clarity and adequacy in order to achieve the objectives of the present study. A preliminary questionnaire was designed and presented to (5) experts for the determination of its validity.

\section{Data Collection}

Dates were collected through interviewing, recording and examination technique (15th November /2018 to25th/ February /2019).

The investigator had introduced her plan to study participant and explained the objective, and the benefit of the study. Verbal consent to participate in the study was obtained from each 
woman by explaining then it was voluntary and confidential, and that the information disclosed would be just for research purposes. All study sample was interviewed by the investigator, in some yard, the interviews were knowledge and attitude about concerning preconception counseling and screening:

\section{Statistical data analysis}

Using two and five-point Likert scales while questions regarding practices focused on single and current use. Chi-square and Mann- Whitney tests were applied to the knowledge, attitudes, and practices of study

\section{Results}

Table 1.Distribution of the study population according to certain socio-demographic characteristics $(N=100)$ and association with knowledge of study sample and attitude.

\begin{tabular}{|c|c|c|c|c|c|}
\hline \multirow{3}{*}{ Items } & \multicolumn{4}{|c|}{ Chi-Square Tests } & \\
\hline & \multirow{2}{*}{ No /F\% } & \multicolumn{2}{|c|}{ Knowledge } & \multicolumn{2}{|l|}{ Attitude } \\
\hline & & P Value & Sig & P Value & Sig \\
\hline Age groups & No $/ \mathrm{F} \%$ & & & & \\
\hline$>20$ & 14 & & & & \\
\hline $20-25$ & 75 & .05 & $\mathrm{~S}$ & .03 & $\mathrm{~S}$ \\
\hline $26-30$ & 9 & & & & \\
\hline $31-35$ & 2 & & & & \\
\hline Mean $\pm S D=23.12 \pm 3.108$ & 100 & & & & \\
\hline GENDER & No $/ \mathrm{F} \%$ & P Value & Sig & P Value & sig \\
\hline Male & 37 & & & & \\
\hline Female & 63 & .05 & S & .05 & S \\
\hline STUDY & No $/ \mathrm{F} \%$ & P Value & Sig & P Value & Sig \\
\hline Moring & 55 & & & & \\
\hline Evening & $\begin{array}{l}45 \\
100\end{array}$ & .001 & HS & .1 & NS \\
\hline Education mother & No /F\% & P Value & Sig & $\mathrm{P}$ Value & Sig \\
\hline Not read \& write & 7 & & & & \\
\hline Read write \& & 12 & & & & \\
\hline Primary school & 11 & & & & \\
\hline Intermediate school & 31 & 0.4 & NS & 0.3 & NS \\
\hline Secondary school & 24 & & & & \\
\hline Others & 15 & & & & \\
\hline & 100 & & & & \\
\hline Education father & No $/ \mathrm{F} \%$ & $\mathrm{P}$ Value & Sig & $\mathrm{P}$ Value & Sig \\
\hline Not read \& write & 2 & & & & \\
\hline Read write \& & 9 & & & & \\
\hline Intermediate school & 3 & & & & \\
\hline Primary school & 9 & 0.9 & NS & 0.5 & NS \\
\hline Secondary school & 21 & & & & \\
\hline Others & 56 & & & & \\
\hline & 100 & & & & \\
\hline Occupation mother & $\mathrm{No} / \mathrm{F} \%$ & P Value & Sig & P Value & Sig \\
\hline House wife & 58 & & & & \\
\hline Employee & 37 & 0.9 & NS & 0.4 & NS \\
\hline Retuned & 2 & & & & \\
\hline
\end{tabular}




\begin{tabular}{|c|c|c|c|c|c|}
\hline \multirow{3}{*}{ Items } & \multirow{3}{*}{ No /F\% } & \multicolumn{3}{|c|}{ Chi-Square Tests } & \multirow{3}{*}{ Sig } \\
\hline & & \multicolumn{2}{|c|}{ Knowledge } & Attitude & \\
\hline & & P Value & Sig & P Value & \\
\hline Private job & $\begin{array}{l}3 \\
100\end{array}$ & & & & \\
\hline Occupation father & No $/ \mathrm{F} \%$ & P Value & Sig & $\mathrm{P}$ Value & Sig \\
\hline Not work & 13 & & & & \\
\hline Employee & 49 & & & & \\
\hline Retired & 16 & 0.4 & NS & 0.04 & $S$ \\
\hline Free profession & $\begin{array}{l}22 \\
100\end{array}$ & & & & \\
\hline Number family & No /F\% & $\mathrm{P}$ Value & Sig & $\mathrm{P}$ Value & Sig \\
\hline $3-4$ & 17 & & & & \\
\hline $5-6$ & 36 & & & & \\
\hline $7-8$ & 26 & 0.50 & NS & 0.1 & NS \\
\hline $9-10$ & 17 & & & & \\
\hline $11-12$ & 4 & & & & \\
\hline $\begin{array}{l}\text { Range among member } \\
\text { family }\end{array}$ & No /F\% & $\mathrm{P}$ Value & Sig & $\mathrm{P}$ Value & Sig \\
\hline $1-2$ & 42 & & & & \\
\hline $3-4$ & 44 & & & & \\
\hline $5-6$ & 11 & 0.00 & HS & 0.4 & NS \\
\hline$\leq 7$ & $\begin{array}{l}3 \\
100\end{array}$ & & & & \\
\hline House & No /F\% & P Value & Sig & $\mathrm{P}$ Value & Sig \\
\hline Own & 85 & & & & \\
\hline Rent & 15 & 0.8 & NS & 0.9 & NS \\
\hline $\begin{array}{l}\text { Monthly income } \\
\text { Enough to some extent }\end{array}$ & $\begin{array}{l}\text { No } / \mathrm{F} \% \\
80\end{array}$ & P Value & Sig & $\mathrm{P}$ Value & Sig \\
\hline Not enough & $\begin{array}{l}20 \\
100\end{array}$ & 0.5 & NS & 0.01 & HS \\
\hline Residence & No $/ F \%$ & $\mathrm{P}$ Value & Sig & $\mathrm{P}$ Value & Sig \\
\hline Urban & 59 & & & & \\
\hline Rural & 5 & & & & \\
\hline Village & 4 & $0.0 \mathrm{~S}$ & S & 0.05 & S \\
\hline Area & 8 & & & & \\
\hline District & $\begin{array}{l}24 \\
100\end{array}$ & & & & \\
\hline $\begin{array}{l}\text { Relationship between } \\
\text { parents }\end{array}$ & No $/ \mathrm{F} \%$ & $\mathrm{P}$ Value & Sig & $\mathrm{P}$ Value & Sig \\
\hline Yes & 55 & & & & \\
\hline No & $\begin{array}{l}45 \\
100\end{array}$ & 0.6 & NS & 0.5 & NS \\
\hline $\begin{array}{l}\text { Having hereditary disease in } \\
\text { the family }\end{array}$ & No $/ F \%$ & P Value & Sig & $\mathrm{P}$ Value & Sig \\
\hline $\begin{array}{l}\text { Yes } \\
\text { No }\end{array}$ & $\begin{array}{l}17 \\
83\end{array}$ & 0.7 & NS & 0.31 & NS \\
\hline $\begin{array}{l}\text { Source information about } \\
\text { premarital screening }\end{array}$ & No /F\% & $\mathrm{P}$ Value & Sig & $\mathrm{P}$ Value & Sig \\
\hline
\end{tabular}




\begin{tabular}{llllll}
\hline \multirow{2}{*}{ Items } & \multicolumn{4}{c}{ Chi-Square Tests } \\
\cline { 2 - 6 } & \multirow{2}{*}{ No /F\% } & \multicolumn{2}{l}{ Knowledge } & Attitude \\
\cline { 5 - 6 } & & P Value & Sig & P Value & Sig \\
\hline Friend and relative & 30 & & & & \\
TV and Radio & 9 & & & & NS \\
Magazine \& newspaper & 37 & 0.5 & NS & 0.4 & \\
Internet & 17 & & & & \\
Lectures & 5 & & & & \\
& 100 & & & & \\
\hline
\end{tabular}

The majority of study sample in age group (20-25) years old,and majority of sample study was (female $(63 \%)$ in Moring about parent of student, The study showed the highest educational rate for parents (mothers(56\%)of them was Intermediate school), while father $\mathrm{s}$ (\%56 was others level education). For occupation of parents, the highest percentage of mothers was housewives $(58 \%)$ and fathers $(49 \%)$ was employee,the higher percentage of number student family with group (5-6).the range student among Brothers was (44\%) with group(3-4)(85\%)of them own house and monthly income was( $80 \%)$ was enough live $(59 \%)$ of them in urban ears $(55 \%)$ of them no have hereditary disease, $(30 \%)$ they have source information from them friend and relative.

Table 2. Students' knowledge about premarital screening with mean score.

\begin{tabular}{|c|c|c|c|}
\hline No & Items & mean & Assess \\
\hline 1 & $\begin{array}{l}\text { Pre-marital tests are defined as the laboratory tests that the } \\
\text { young man or the next young woman undergoes }\end{array}$ & 1.9 & Good \\
\hline 2 & of premarital screening & & \\
\hline $1-2$ & Protecting spouses from health and psychological problems & 1.9 & Good \\
\hline $2-2$ & $\begin{array}{l}\text { Protection of offspring by the birth of healthy children } \\
\text { mentally and physically }\end{array}$ & 1.9 & Good \\
\hline $3-2$ & Protecting the community from the birth of disabled children & 1.9 & Good \\
\hline $4-2$ & Conduct a routine of gain material for health protection only & 1.5 & moderate \\
\hline $5-2$ & Time for prenuptial examination & 1.9 & Good \\
\hline $6-2$ & Time of post-marriage examination & 1.4 & poor \\
\hline $7-2$ & It is possible to perform the examination at any health center & 1.5 & moderate \\
\hline $8-2$ & It is possible to perform the examination in a private hospital & 1.4 & poor \\
\hline $9-2$ & Conducting the examination in a public hospital & 1.9 & Good \\
\hline & grad mean & 1.7 & moderate \\
\hline 3 & premarital screening include & & \\
\hline $1-3$ & $\begin{array}{l}\text { Detecting the health history of the family (mental and } \\
\text { physical disabilities and chronic diseases }\end{array}$ & 1.8 & moderate \\
\hline $2-3$ & Examination of the blood type and the RH factor & 1.9 & Good \\
\hline $3-3$ & Examination of early detection of genetic diseases & 1.8 & moderate \\
\hline $4-3$ & Fertility examination of the couple & 1.3 & poor \\
\hline $5-3$ & Other tests such as (toxoplasmosis) (cat disease) & 1.7 & moderate \\
\hline $6-3$ & Including the mental health history of the disease & & \\
\hline $7-3$ & Mental disability such as Down syndrome & 1.6 & moderate \\
\hline $8-3$ & Chronic diseases (such as diabetes) & 1.7 & moderate \\
\hline $9-3$ & Genital dislocation diseases (pelvic dislocation) & 1.4 & poor \\
\hline $\begin{array}{l}10- \\
3\end{array}$ & Blood disease like HEMOPHILIA & 1.8 & moderate \\
\hline
\end{tabular}




\begin{tabular}{|c|c|c|c|}
\hline No & Items & mean & Assess \\
\hline $\begin{array}{l}11- \\
3\end{array}$ & Possible diagnosis of sexually transmitted diseases. & 1.6 & moderate \\
\hline $\begin{array}{l}12- \\
3\end{array}$ & The incidence of diseases in increases with relative marriage & 1.6 & moderate \\
\hline $\begin{array}{l}13- \\
3\end{array}$ & Investigation of male mumps in adulthood & 1.5 & moderate \\
\hline & grad mean & 1.65 & moderate \\
\hline 4 & RH type is cause health problem & & \\
\hline $1-4$ & Father have positive $\mathrm{RH}$ and mother have negative is problem & 1.4 & poor \\
\hline $2-4$ & $\begin{array}{l}\text { Father have negative } \mathrm{RH} \text { and mother have positive is problem } \\
\text { grad mean }\end{array}$ & $\begin{array}{l}1.3 \\
1.35\end{array}$ & $\begin{array}{l}\text { poor } \\
\text { poor }\end{array}$ \\
\hline 5 & What is the meaning of a person with genetic traits? & & \\
\hline $1-5$ & $\begin{array}{l}\text { A person carries the traits for heredity blood disease and has } \\
\text { symptoms }\end{array}$ & 1.7 & moderate \\
\hline $2-5$ & $\begin{array}{l}\text { A person carries the traits for heredity blood disease and has } \\
\text { not shown symptoms }\end{array}$ & 1.5 & moderate \\
\hline & grad mean & 1.6 & moderate \\
\hline 6 & Vaccination for women before marriage & & \\
\hline $1-6$ & rubella & 1.7 & moderate, \\
\hline $2-6$ & Tetanus vaccine & 1.4 & poor \\
\hline $3-6$ & Malaria vaccine & 1.5 & moderate, \\
\hline 4-6 & Pulmonary tuberculosis & 1.6 & moderate, \\
\hline $5-6$ & Flu & 1.4 & poor \\
\hline $6-6$ & $\begin{array}{l}\text { Typhoid } \\
\text { grad mean }\end{array}$ & $\begin{array}{l}1.5 \\
1.5\end{array}$ & $\begin{array}{l}\text { moderate, } \\
\text { moderate, }\end{array}$ \\
\hline 7 & Cause of infectious disease transmission & & \\
\hline $1-7$ & Bacteria & 1.7 & moderate, \\
\hline $2-7$ & Viruses & 1.8 & moderate, \\
\hline $3-7$ & Parasites & 1.7 & moderate, \\
\hline 4-7 & Insects & 1.6 & moderate, \\
\hline $5-7$ & $\begin{array}{l}\text { Worms } \\
\text { grad mean }\end{array}$ & $\begin{array}{l}1.5 \\
1.66\end{array}$ & $\begin{array}{l}\text { moderate, } \\
\text { moderate, }\end{array}$ \\
\hline 8 & Methods of transmission & & \\
\hline $1-8$ & Transmission of infection to pulmonary tuberculosis & 1.8 & moderate, \\
\hline $2-8$ & $\begin{array}{l}\text { Through breathing during coughing, sneezing and mucous } \\
\text { discharge }\end{array}$ & 1.9 & Good \\
\hline $3-8$ & Through sexual intercourse & 1.9 & Good \\
\hline $4-8$ & Over eating and drinking with the infected person & 1.8 & moderate, \\
\hline $5-8$ & Cross the blood from mother to child & 1.8 & moderate, \\
\hline $6-8$ & Through breastfeeding from infected mother's milk & 1.8 & moderate, \\
\hline $7-8$ & Methods of transmission of toxoplasmosis & 1.6 & moderate, \\
\hline $8-8$ & Over eating from food not cooked well & 1.7 & moderate, \\
\hline $9-8$ & Through sexual intercourse & 1.8 & moderate, \\
\hline $\begin{array}{l}10- \\
8\end{array}$ & Cross the placenta from mother to child & 1.8 & moderate, \\
\hline $\begin{array}{l}11- \\
8\end{array}$ & By transfusion of contaminated blood & 1.9 & Good \\
\hline 9 & $\begin{array}{l}\text { grad mean } \\
\text { For prevention }\end{array}$ & 1.8 & $\begin{array}{l}\text { moderate, } \\
\text { Good }\end{array}$ \\
\hline
\end{tabular}




\begin{tabular}{|c|c|c|c|}
\hline No & Items & mean & Assess \\
\hline $1-9$ & $\begin{array}{l}\text { Wash hands thoroughly with soap and water before and after } \\
\text { food }\end{array}$ & 1.9 & Good \\
\hline $2-9$ & The food is cooked well and specially (meat / eggs / fish) & 1.9 & Good \\
\hline $3-9$ & Wash fruits and vegetables well & 1.9 & Good \\
\hline $4-9$ & $\begin{array}{l}\text { Keep away from the cats and protruding and the soil that you } \\
\text { are defecating }\end{array}$ & 1.9 & Good \\
\hline $5-9$ & $\begin{array}{l}\text { Dispose of waste well } \\
\text { grad mean }\end{array}$ & $\begin{array}{l}1.9 \\
1.9\end{array}$ & $\begin{array}{l}\text { Good } \\
\text { Good }\end{array}$ \\
\hline
\end{tabular}

"In this Table present students' knowledge about premarital screening with mean score for all items was 1.7 there moderate knowledge by interval period (mean score was $=1.5$ then, $>1.5$-poor, $1.5-1.8=$ moderate and $\leq 1.9=$ good)

Table3. Students' Attitudes about premarital screening with mean score.

\begin{tabular}{|c|c|c|c|}
\hline No & Items & mean & Assess \\
\hline 1 & Perception & & \\
\hline $1-1$ & $\begin{array}{l}\text { I think that prenatal screening reduce the risk of heredity diseases } \\
\text { for future generations }\end{array}$ & 4.7 & Good \\
\hline $2-1$ & $\begin{array}{l}\text { it is agreed that prenatal screening reduce the risk of sexually } \\
\text { transmitted diseases between spouses }\end{array}$ & 3 & moderate \\
\hline $3-1$ & $\begin{array}{l}\text { I think that prenuptial screening reduce the risk of infectious } \\
\text { diseases such as tuberculosis }\end{array}$ & 2.1 & poor \\
\hline $4-1$ & $\begin{array}{l}\text { I do not care about this matter, it is up to my family } \\
\text { grad mean }\end{array}$ & $\begin{array}{l}2.3 \\
3\end{array}$ & $\begin{array}{l}\text { poor } \\
\text { moderate }\end{array}$ \\
\hline 2 & Intensity perception (approval of prenuptial examinations & & \\
\hline $1-2$ & $\begin{array}{l}\text { detected heredity diseases that cause disabilities or deformity of } \\
\text { embryos }\end{array}$ & 4 & moderate \\
\hline $2-2$ & $\begin{array}{l}\text { detected Sexually transmitted diseases that cause death or } \\
\text { deformity of the fetus }\end{array}$ & 4.2 & Good \\
\hline $3-2$ & detected Infectious diseases such as tuberculosis & 3.8 & moderate \\
\hline $4-2$ & $\begin{array}{l}\text { Reduces health problems that may lead to a deviation in } \\
\text { pregnancy health }\end{array}$ & 4.1 & Good \\
\hline $5-2$ & Reduce anxiety and psychological disorders between spouses & 4 & moderate \\
\hline $6-2$ & Infertility cases are detected in women & 3.2 & moderate \\
\hline $7-2$ & Infertility is detected in men & 3 & moderate \\
\hline $8-2$ & Different types of blood and $\mathrm{Rh}$ & 4.4 & Good \\
\hline $9-2$ & $\begin{array}{l}\text { The lack of vaccine is important for women } \\
\text { grad mean }\end{array}$ & $\begin{array}{l}3.7 \\
3.8\end{array}$ & $\begin{array}{l}\text { moderate } \\
\text { moderate }\end{array}$ \\
\hline 3 & Self - efficacy & & \\
\hline $1-3$ & $\begin{array}{l}\text { Refusal to marry relatives because they increase the proportion of } \\
\text { genetic diseases such as (thalassemia) }\end{array}$ & 3 & moderate \\
\hline $2-3$ & $\begin{array}{l}\text { Urge my partner to take the correct examination before marriage } \\
\text { and not to evade it }\end{array}$ & 4 & moderate \\
\hline $3-3$ & $\begin{array}{l}\text { Change the decision of marriage when the result of negative } \\
\text { results }\end{array}$ & 2.2 & poor \\
\hline $4-3$ & $\begin{array}{l}\text { The role of religious leader in society is very important in urging } \\
\text { pre-marital examinations }\end{array}$ & 4.5 & Good \\
\hline & grad mean & 3.45 & moderate \\
\hline 4 & Approval of education on prenuptial examinations & & \\
\hline
\end{tabular}




\begin{tabular}{|c|c|c|c|}
\hline No & Items & mean & Assess \\
\hline $1-4$ & $\begin{array}{l}\text { I agree to inform my partner that there is infectious disease or } \\
\text { chronic disease }\end{array}$ & 3.4 & moderate \\
\hline $2-4$ & Perform any medical examination or blood test before marriage & 4 & moderate \\
\hline $3-4$ & I do not do may parental rejection tests & 3.6 & moderate \\
\hline $4-4$ & $\begin{array}{l}\text { I do not know anything about genetic diseases in my family } \\
\text { grad mean }\end{array}$ & $\begin{array}{l}3.9 \\
3.72\end{array}$ & $\begin{array}{l}\text { moderate } \\
\text { moderate }\end{array}$ \\
\hline 5 & Encourage on & & \\
\hline $1-5$ & $\begin{array}{l}\text { Take lectures about premarital screening in university study is } \\
\text { necessary to raise awareness. }\end{array}$ & 3.8 & moderate \\
\hline $2-5$ & To give lectures on premarital screening at health centre. & 3.9 & moderate \\
\hline $3-5$ & $\begin{array}{l}\text { premarital screening even it cause cancel marriage because the } \\
\text { disease effect on future generations }\end{array}$ & 4 & moderate \\
\hline $4-5$ & $\begin{array}{l}\text { Conduct premarital screening because it does not violate our } \\
\text { religious beliefs }\end{array}$ & 3.3 & moderate \\
\hline $5-5$ & $\begin{array}{l}\text { Introduce the subject of premarital screening in the curriculum of } \\
\text { secondary school }\end{array}$ & 4 & moderate \\
\hline $6-5$ & $\begin{array}{l}\text { Religious leader should adopt the ideas premarital screening in } \\
\text { their discussion }\end{array}$ & 4 & moderate \\
\hline & grad mean & 3.83 & moderate \\
\hline 6 & Agreement on premarital screening & & \\
\hline $1-6$ & $\begin{array}{l}\text { Contribute to reduction of prevalence of heredity diseases in } \\
\text { community. }\end{array}$ & 4 & moderate \\
\hline $2-6$ & $\begin{array}{l}\text { Contribute to the early detection of any defect in fertility or } \\
\text { reproductive capacity for women }\end{array}$ & 3.9 & moderate \\
\hline $3-6$ & Contribute detection low immunity against rubella among women & 3.7 & moderate \\
\hline $4-6$ & $\begin{array}{l}\text { Contribute to reducing the spread of sexually transmitted diseases } \\
\text { in society }\end{array}$ & 4.1 & Good \\
\hline $5-6$ & Ensure the future partner health & 4.3 & Good \\
\hline $6-6$ & Is a preventive measure & 4.1 & Good \\
\hline $7-6$ & Prevent future transmission of diseases to my children & 4.2 & Good \\
\hline $8-6$ & $\begin{array}{l}\text { Reduce the cost to the individual and family because of the } \\
\text { disease to generation. }\end{array}$ & 4.5 & Good \\
\hline $9-6$ & $\begin{array}{l}\text { Useful to community reduces the birth of dead and children with } \\
\text { disabilities }\end{array}$ & 4.5 & Good \\
\hline $\begin{array}{l}10- \\
6\end{array}$ & Ensure health marriage & 4.1 & Good \\
\hline $\begin{array}{l}11- \\
6\end{array}$ & $\begin{array}{l}\text { Give an opportunity for these who get married to get pre-marital } \\
\text { treatment through early detection of disease }\end{array}$ & 4 & moderate \\
\hline & grad mean & 4 & moderate \\
\hline 7 & barrier to taking action about premarital screening & & \\
\hline $1-7$ & Waste of time & 2.6 & poor \\
\hline $2-7$ & Against Islamic roles & 2.6 & poor \\
\hline $3-7$ & Breaks personal privacy of health status & 2.4 & poor \\
\hline $4-7$ & I'm ashamed of the tests & 2.5 & poor \\
\hline & grad mean & 2.52 & poor \\
\hline 8 & Attitude student among premarital screening & & \\
\hline $1-8$ & Break the personal privacy of the health situation & 3.3 & moderate \\
\hline $2-8$ & $\begin{array}{l}\text { Misuse of the reputation of an individual with an inherited or } \\
\text { sexually transmitted disease, which affects the possibility of marriage }\end{array}$ & 3. & moderate \\
\hline
\end{tabular}




\begin{tabular}{llll}
\hline \hline No & Items & mean & Assess \\
\hline $3-8$ & Its cost is expensive & 2.9 & poor \\
4-8 & A dispute they are engaged (termination marriage) & 2.9 & poor \\
& grad mean & 3. & moderate \\
9 & Agreement on the cause don'ts premarital screening & & \\
1-9 & Information who to get married very few test & 4.2 & Good \\
2-9 & The Weak role of health centers in community awareness & 3.7 & moderate \\
3-9 & Weak role of the clergy in awareness of the community & 3.4 & moderate \\
4-9 & Weak role of educational intuitions and educational awareness of & 3.4 & moderate \\
the test & Opposes the will of God & 2.9 & poor \\
6-9 & My family will refuse to marry & 2.9 & poor \\
7-9 & Cause insulting me & 2.4 & poor \\
8-9 & I am afraid of the test result & 2.9 & poor \\
& grad mean & 3.22 & moderate \\
Total grad mean & 3.99 & moderate \\
\hline
\end{tabular}

In this Table present 'attitude about premarital screening with mean score for all items was 3.99 there moderate attitude by interval period (mean score was $=3$ then, $>3$-poor,3$4=$ moderate and $\leq 4.1=$ good

\section{Discussion}

The majority of study sample in age group (20-25) years old , and majority of sample study was (female $63 \%$ ) in Moring about parent of student, The study showed the highest educational rate for parents (mothers $(56 \%)$ of them was Intermediate school ), while father $\mathrm{s}$ (\%56 was others level education ). For occupation of parents, the highest percentage of mothers was housewives(58\%) and fathers (49\%) was employee, the higher percentage of number student family with group (5-6).the range student among Brothers was (44\%) with group (3-4)(85\%)of them own house and monthly income was $(80 \%)$ was enough live $(59 \%)$ of them in urban ears $(55 \%)$ of them no have hereditary disease , $(30 \%)$ they have source information from them friend and relative. And relationship with knowledge and attitude with Chi-Square Tests the knowledge present significant with age group , gender, number family, residence place live, and monthly income ,while higher significant with types study student only .

No significant found with education level mother and father, occupation Mather and father ,types house ,relationship between student parent family, they have hereditary disease in the family and source information about premarital screening.

Attitude with Chi-Square Tests the present significant with age group, gender, occupation father, and residence .while No significant found with type of study student ,education level mother and father , occupation Mather, number family member ,range among member family, type house, relationship between student parent family, they have hereditary disease in the family and source information about premarital screening.

While Ayalew when his study Women's knowledge and associated factors in preconception care he is found, The median age of the participants was 25 years with an inter quartile range of 11 years.. Hundred and forty nine (35.3\%) of respondents had a monthly household income of less than or equal to 70 Dollar and $131(31 \%)$ were literate. More than half of participants $251(59.5 \%)$ were married and 113(26.8\%) of women were housewives. One hundred and twelve $(25.4 \%)$ and $114(19.8 \%)$ of the participant's husband were market trade vendor and primary school respectively (Ayalew etal.2017), ,. while We found Jordan study by Al-Akour 2015, they found in total, 763 participants (537 women and 226 men) were 
included in the current study. A total of $273(50.8 \%)$ women and $33(14.6 \%)$ men were 20-3 0 years of age. The mean age of women and men was 29.62 years (SD \pm 5.43 ) and 35.59 years (SD \pm 6.13 ), respectively. A total of 303 (56.4\%) women and 101 (44.7\%) men had up to high school education and $322(60.0 \%)$ women and $89(39.4 \%)$ men reported their income per month was less than US \$ 550. The results also revealed that $153(28.5 \%)$ women and 58 (25.7\%) men had consanguineous marriages. Of those who had consanguineous marriages, $67(43.8 \%)$ women and $26(45.8 \%)$ men were fi rst cousin relatives. A total of $259(48.2 \%)$ women and $67(30 \%)$ men had a family history of hereditary diseases and $25(4.7 \%)$ women and $7(3.1 \%)$ men had children with birth defects. As to the obstetric history of the participants, the results found that $341(63.5 \%)$ women reported currently using one birth control method; 260 (48.4\% ) women and 97 (42.9\%) men reported that their wives' last pregnancy was unplanned. Of the women, 53 (10\%) had a history of infertility; 61 (11.4) had premature babies; $85(10.8 \%)$ had a history of intrauterine fetal death and 16 (3\%) had a newborn with birth defects (A 1-Akou,etal 2015). (We did not find a similar study on the students of the college and especially students of the Faculty of Nursing this is the first study applied to the students of the college, the importance of the subject and to guide the Iraqi Ministry of Health on the importance of study on the health of society and the new generation )

Students' knowledge about premarital screening with mean score in table (1) present in items (Pre-marital tests are defined as the laboratory tests that the young man or the next young woman undergoes) present good mean that mean most student agree with important premarital screening .but in total item found In this Table present students' knowledge about premarital screening with mean score for all items was 1.7 there moderate knowledge . (AndargachewKass. 2018) To determine the knowledge level of healthcare providers of effective knowledge of preconception care, they found There is poor knowledge among most of the healthcare providers. The proportion of healthcare providers who exhibited an acceptable level or higher knowledge was $31 \%$. About one fourth $(26 \%)$ of the s were found with medium or fair level of knowledge. The remaining $43 \%$ had low or poor knowledge. The odds of having good knowledge was high among HCPs working in Hospitals using their smart phone to access clinical resources, among those)( Andargachew ,etal .2018).

Students' Attitudes about premarital screening with mean score the study present in total items of attitudes premarital screening with mean score for all items was 3.99 there moderate attitude the same found study in previous study, with Another barrier to nursing staff attitude is poor attitude and knowledge among both health care providers and consumers of health services. Therefore, increasing knowledge and improving attitudes about the potential for to reduce poor obstetrical outcomes is necessary in both professional and patient groups. Studies have shown that women may not perceive themselves to be at risk for a poor obstetrical outcome and, therefore, would not seek consultation before becoming pregnant. Women who were younger, had less education, and perceived themselves to be less healthy were more likely to believe that they had little influence on the outcome of their pregnancy (Weisman et al., 2008)

\section{Conclusions}

The study on preconception counseling and screening .may be considered to be very important for increasing students' knowledge of post-graduate community education.

- $\quad$ The majority of study sample in age group (20-25) years old , and majority of sample study was (female(63\%) in Moring about parent of student, The study showed the highest educational rate for parents (mothers $(56 \%)$ of them was Intermediate school ), while father s (\%56 was others level education ). For occupation of parents, the highest percentage of mothers was housewives(58\%) and fathers (49\%) was employee, the higher percentage of 
number student family with group (5-6).the range student among Brothers was (44\%) with group (3-4)(85\%)of them own house and monthly income was $(80 \%)$ was enough live $(59 \%)$ of them in urban ears $(55 \%)$ of them no have hereditary disease , $(30 \%)$ they have source information from them friend and relative.

- In this Table present students' knowledge about premarital screening with mean score for all items was 1.7 there moderate knowledge .

- In this Table present 'attitude about premarital screening with mean score for all items was 3.99 there moderate attitude .

\section{Recommendations}

Conduct continuing education programs for preconception counseling and screening for high school and university students, And to increase cooperation between the Ministries of Higher Education and Scientific Research and the Ministry of Health and the Environment to develop a strategy to increase the knowledge of university students about the importance of pre-marriage examinations and to strengthen the role of clergy in ensuring the conduct of premarital tests to reduce genetic and infectious diseases among members of society

\section{References}

1. Allport, G. W. (1935). Attitudes. In Murchison C. (Ed.), Handbook of social psychology (pp. 798-844). Worcester,

2. Al-Akour1, R. SouUb1,K. Mohammad1 \&F.Zayed2014. Awareness of preconception care among women and men: A study from Jordan. Journal of Obstetrics and Gynaecology, April 2015; 35: 246-250 (C) 2015 Informa UK, Ltd. ISSN 0144-3615 print/ISSN 1364-6893 online DOI: $10.3109 / 01443615.2014 .958145$

3. ACOG. (2005, September). The Importance of Preconception Care in the Continuum of Women's Health Care. American Congress of Obstetrics and Gynaecologists. Retrieved March 6th, 2015, from http://www.acog.org

4. ACOG. (2015, March). Good Health Before Pregnancy: Preconception Care. (American Congress of Obstetricians and Gynecologists) Retrieved March 27, 2017, from www.acog.org: http://www.acog.org

5. Autism Speaks. (2017). Avoiding Toxic Exposures During Pregnancy. ( Autism Speaks Inc.) Retrieved March 28, 2017, from www.autismspeaks.org: https://www.autismspeaks.org

6. Baby center. (2017, March). Preconception checkup: Why you need one and what to expect. (B. M. Board, Editor) Retrieved 2017, from www.babycenter.com: https://www.babycenter.com

7. CDC. (2016, July 20). Centers for Disease Control and Prevention. Retrieved March 28, 2017, from www.cdc.gov: https://www.cdc.gov

8. CDC. (2016, July 21). Centers for Disease Control and Prevention. Retrieved March 28, 207, from www.cdc.gov: https://www.cdc.gov

9. Dean, S., Zohra, S., Ayesha, M., \&Bhutta, A. (2014, september 26th). Preconception care: promoting reproductive planning. Reproductive Health, 11. doi:10.1186/1742-4755-11S3-S2

10. Fraser, D. M., Cooper, M. A., \& Nolte, A. G. (2006). Myles Textbook for Midwives (14th ed.). EDINBURGH: Elsevier Limited.

11. Gelman, L. (2017). Heath 101: Gentic Testing Before and During Pregnancy. (G. Lauren, Producer, \& Meredith corporation) Retrieved March 27, 2017, from http://www.parents.com: http://www.parents.com

12. Jean, C. F., Kizito, P., Lumumba, V., Guilkey, D., \&Wamukoya, M. (2011). Levels, Trends, and Differentials in Family Planning and Reproductive Health Indicators in Urban 
Kenya. Narobi: Measurement, Learning \& Evaluation Project. Retrieved June 18, 2015, from https://www.urbanreproductivehealth.org

13. JENNY STERN,2015. Preconception Health and CareA Window of Opportunity .Digital Comprehensive Summaries of Uppsala Dissertations from the Faculty of Medicine 1160. ISSN 1651-6206 ISBN 978-91-554-9402-5 urn:nbn:se:uu:diva-265542. ACTA UNIVERSITATIS UPSALIENSIS UPPSALA 2015

14. KAIS. (2014). Kenya AIDS Indicator Survey 2012. Nairobi: Kenya National AIDS \& STI Control Programme-NASCOP. Retrieved June 17th, 2015, from www.nacc.or.ke 15. LUAAYABDULWAHEDSHIHAB, ABDUKAREEMALIQASSIM \& ISRAA HUSSIN ABD , NURSES AND COMPUTER-BASED NURSING DOCUMENTATION SYSTEM AT, International Journal of General Medicine, and Pharmacy (IJGMP), ISSN(P): 2319-3999; ISSN(E): 2319-4006, Vol. 4, Issue 1, Jan 2015, 105-112 .

16. Mason E, et al. Preconception care; advancing from important to do and can be done to is being done and is making a difference, in low income countries. Reprod Health. 2014;11(3):

17. Michael, C. (2007, August). Recommendations for Preconception Care. American Family Physician. Retrieved March 6th, 2015, from http://www.aafp.org

18. MOH. (2011). Maternal Care Package A Guide to field Healthcare workers. Sri Lanka: WHO. Retrieved january 14, 2015

19. MOH. (2012). Community Midwifery Services in Kenya Implementation Guidelines. Nairobi: Ministry of Health.

20. MoPHS; MoMS. (2007). Training Manual for Health Workers on Prevention, Early identification and Intervention of Disabilities. Nairobi: Republic of Kenya. Retrieved 2015, from kenya.cbm.org

21. MoPHS; MoMS. (2012). National guidelines for quality Obstetrics and Perinatal care. Nairobi: Republic of Kenya. Retrieved June 18, 2015, from https://www.k4health.org

22. New York State Department of Health AIDS Institute. (2010, July). Preconception Care for HIV-Infected Women. Retrieved January 25th, 2015, from HIV Clinical Resource: http://www.hivguidelines.org

23. Ruhl, C., \& Moran, B. (2008). The clinical content of preconception care:preconception care for special populations. Retrieved january 25th, 2015, from http://www.beforeandbeyond.org

24. Sohni, D. V., Elizabeth, M. M., Howson, C. P., Zohra, L. S., Ayesha, I. M., \&Solfiqar, B. A. (2013). Born Too Soon: Care before and between pregnancyto prevent preterm births: from evidence to action. Reproductive Health. doi:doi:10.1186/1742-4755-10$\mathrm{S} 1-\mathrm{S} 3$

25. Sohni, D. V., Elizabeth, M. M., Howson, C. P., Zohra, L. S., Ayesha, I. M., \&Solfiqar, B. A. (2013). Born Too Soon: Care before and between pregnancytoprevent preterm births: from evidence to action. Reproductive Health. doi:doi:10.1186/1742-4755-10S1-S3

26. Tuomainen, H., Cross, L. B., Bhoday, M., Qureshi, N., \& Kai, J. (2013, July 23rd). Opportunities and challenges for enhancing preconception health in primary care: qualitative study with women from ethnically diverse communities. BioMedical Journal Open, 3(7). doi:10.1136/bmjopen-2013-002977

27. WHO. (2013). Maternal mortality in 1990-2013. Retrieved June 20, 2014, from Maternal Health by Country: www.who.int

28. Williams, Letitia; Zapata; D'Angelo; Harrison; Morrow (2012). "Associations between preconception counseling and maternal behaviors before and during pregnancy". Matern Child Health J. 16: 1854-1861. doi:10.1007/s10995-011-0932-4.

29. Young, C. T., Arquia, M. L., \& Ray, J. T. (2013, september 3). Preconception Care in 
Low- and Middle-Income Countries: New Opportunities and a New Metric. PLoS Med, 10(9). doi:10.1371/journal.pmed.1001507

\section{Dr.sundss. baqer dawood ${ }^{1 \& 2}$ Dr. saijjadsalim Issa ${ }^{2}$ Dr.Jenanakbershakoor ${ }^{3}$.Kazem J. almadwah $^{4}$}

1. PhD.in maternity nursing- university of basrah

2. Board in family medicine- university of basrah

3. PhD.in maternity nursing- university of karkuk

4.master pediatric nursing - university of basrah.

1- 'Sundss Baqer Dawood, " teacher, College of Nursing, FOR fundamental department University of BASRA $\underline{\text { Sundss.b.dawod@gmail.com }}$

07707096503

https ://orcid. org/000-0002-6061-3867

${ }^{2-{ }^{* *}}$ Saijjad Salim Issa, ${ }^{* *}$ AssistanceProfessor medicine , College of Nursing, fundamental department ,University of BASRAsajjadalattar@yahoo.com

07801230692

https ://orcid. org/000-0002-7079-9968

3-*** Jenan Akber Shakoor*** Assistance Professor nursing ,fundamental department

,College of Nursing, University of Karkuk jinanshukur@uokirkuk.edu.iq

$\underline{07714950008}$

4- $* * * *$ Kadhim Jawad_AssistanceLecturer,College of Nursing, FOR fundamental department University of BASRAkadhumsalih55@gmail.com

07734622524

https ://orcid. org/000-0002-6340-7666 